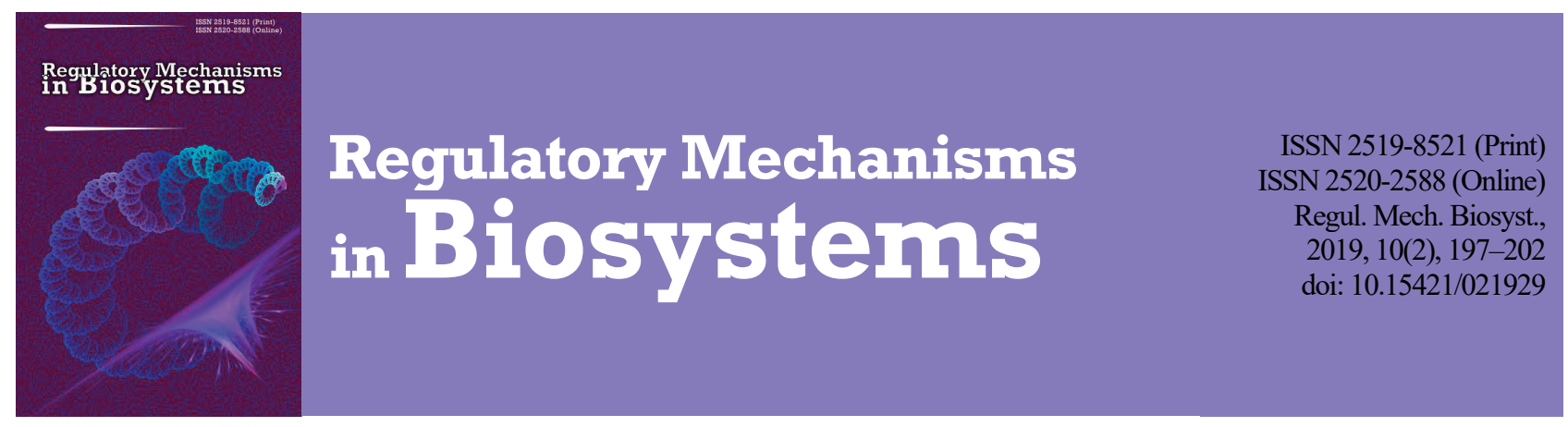

\title{
$X$-ray densitometric indices of proximal phalanx, medial phalanx and ungular pelvic limb bones as criteria for age diagnosis of cattle in forensic veterinary expertise
}

\author{
I. V. Yatsenko*, S. A. Tkachuk**, L. V. Busol*, M. M. Bondarevsky*, I. V. Zabarna***, I. A. Biben**** \\ *Kharkiv State Animal Veterinary Academy, Kharkiv, Ukraine \\ **National University of Life and Environmental Sciences of Ukraine, Kyiv, Ukraine \\ ***Podolsky State Agrarian University of Technology, Kamyanets'-Podil's'kyi, Ukraine \\ ****Dnipro State Agrarian and Economic University, Dnipro, Ukraine
}

Article info

Received 16.03.2019

Received in revised form 07.05.2019

Accepted 09.05.2019

Kharkiv State Zooveterinary Academy, Academichna st., I, Mala Danylivka, Dergachi district, Kharkiv region, 62341, Ukraine. Tel.: +38-067-186-06-65.

E-mail:yacenko-1971@ukr.net

National University of Life and Environmental Sciences of Ukraine, Heroiv Oborony st., 15 ,

Kyiv, 03041, Ukraine.

Tel.:+38-067-592-09-00.

E-mail:ohdin@ukr.net

Podolsky State Agrarian University of Technology, Shevchenko st., 13, Kamyanets'-Podil's'kyi, 32300, Ukraine. Tel.:+38-097-744-12-85. E-mail: inna-chornenka@ukr.net

Dnipro State Agrarian and Economic University

Serhii Efremov st., 25 ,

Dnipro, 49600, Ukraine

Tel.: $+38-067-723-11-87$.

E-mail:bibenvet@ukr.net

Yatsenko, I. V., Tkachuk, S. A., Busol, L. V., Bondarevsky, M. M., Zabarna, I. V., \& Biben, I. A. (2019). X-ray densitometric indices of proximal phalanx, medial phalanx and ungular pelvic limb bones as criteria for age diagnosis of cattle in forensic veterinary expertise. Regulatory Mechanisms in Biosystems, 10(2), 197-202. doi:10.15421/021929

\begin{abstract}
Morphological parameters of biological material are extremely informative in diagnostic studies, in particular, to determine the species, sex, time of death, the term of burial. The most informative object for these tasks is the skeleton, because changes in the bones are stored for a long time, while soft tissue is subjected to rotting. Bone tissue is the most durable, but at the same time, it is very labile and reacts to all metabolic processes in the body. The object of the study was proximal phalanx, medial phalanx and ungular bone of the pelvic limb of cattle ranging in age from newborn to 12 years old. Radiography of the proximal phalanx, medial phalanx and ungular bones of the pelvic limb was performed on the Arman apparatus. The bones were subjected to X-ray in the lateromedial projection. The inner and outer sections of the tubular bone were determined. The mathematical modeling of the interaction of X-rays and the cortical layer of bones of fingers (proximal phalanx, medial phalanx and ungular) of cattle was carried out in this work. It is established that this process is described by Bouger's law. The physico-mathematical model of proximal phalanx, medial phalanx and ungular bones has been calculated, on the basis of which it was possible to calculate the X-ray densitometric indices of these bones of cattle. The age features of dynamics of X-ray densitometric indices of the proximal phalanx, medial phalanx and ungular bones were established and a method of determining the age of cattle according to this criterion was proposed. A mathematical model for the proximal phalanx, medial phalanx and ungular bones of the pelvic limbs of cattle that can be applied in X-ray densitometry uses: for the average third proximal phalanx - section of heterogeneous tubular structure modeled by a semicircle; for a medial phalanx bone - a section of a triangular shape; for the ungular bone - a heterogeneous structure, the plantar surface is inscribed in a rectangle. The process of interaction of X-rays with the bone structure of the examined pelvic limb bones can be described by Bouguer's law. The developed mathematical modeling of this interaction and the algorithm for its analysis is the basis for determining the age of cattle for X-ray densitometric indices of the proximal phalanx, medial phalanx and ungular bones of pelvic limbs. By X-ray densitometry of the proximal phalanx and medial phalanx bones of the pelvic limbs extremities one can diagnose the age of bovine animals from birth to 5 years, but according to ungular bones - from birth to 10 years. X-ray densitometry of medial phalanx and ungular bones of pelvic limbs can be used for diagnosing bovine cattle in a complex with other morphological, chemical and physical methods of investigation.
\end{abstract}

Keywords: mathematical model; metatarsus; fingers; relative optical density; osteology.

\section{Introduction}

The bone is a multiphase material composed of a rigid collagen matrix mixed with solid mineral crystals. The mineral provides bone hardness. Without sufficient mineralization, the bone is plastically deformed under load. Collagen provides bone viscosity, making it less fragile, so that it better resists the fracture. The bone adapts to mechanical stress, largely changing the size and shape that are the main factors of resistance to fracture (Turner, 2006). Specific characteristics of the skeleton in different species of mammals are interdependent due to environmental, adaptive (Zotti et al., 2009, 2010), physiological (Stynder, 2008; Coates et al., 2016), specific (McClure et al., 2001) indicators not only in animals but also in humans (Sidoroff et al., 2013).

In addition to the above factors, one of the main factors in creating the effects of muscular load on the bones is a complex network of hormones and growth factors that unite these tissues. One of these hormones, vitamin $\mathrm{D}$, has a profound effect on the calcium content of the muscles and bones, their differentiation and development. Vitamin D deficiency or vitamin $\mathrm{D}$ receptor mutations result in a generalized muscle and bone atrophy, indicating a coordinated action of vitamin D in these areas (Girdis, 2015). The significance of the limb skeleton in general and its individual links is that they carry informative features that are included in the indicators that reliably characterize the species, sex and age belonging to the object of research (Mostafa, 2012; Monfared, 2013).

There are few scientific publications currently available to determine the age and type of species of agricultural animal according to the bones of the fingers or tarsal pelvic limbs. According to scientific results, in some publications, it is clear that the size and density of metacarpal bones of horses and cattle can establish the training stability of horses, species, interspecies features of animals. The authors proved the existence of a correlation between the weight and sex of the animal and the bone mineral density (Keene et al., 2004; Davies et al., 2010).

Thus, a number of factors can be used to assess the characteristics of the species of animals. However, mineral bone density is widely used 
as an indicator of bone health status. A typical method for evaluating bone quality characteristics is densitometric research. Currently, twostatistic X-ray absorptiometry is used, which is often used to assess the bone mineral density of some animals. But, despite the successful use of these systems in many different applications, this is a very costly method that requires timely calibration of the equipment, its reliability and cost-effectiveness. Thus, scientists have studied the possibility of developing a new, affordable and reliable single X-ray absorption system. The method is to use a single X-ray source, $\mathrm{X}$-ray sensor and computer platform, which together, in general, will allow you to calculate the mineral density of the bone (Jimenez-Mendoza et al., 2011). Known methods of computed tomography, digital radiography, and magnetic resonance are sufficiently sensitive to study bone residual material and to determine the causes of death of animals (Amadasi et al., 2014).

The degree of absorption of X-ray radiation by the bone, depending on its parameters (density, chemical composition, thickness), allows us to quantify the method of X-ray densitometry (Dicken, 2015). The application of X-ray densitometry in combination with mathematical modeling methods allows us to determine age-related densitometric characteristics of bones. This, in turn, allows us to apply an X-ray densitometric method in forensic veterinary medicine to determine the age-specificity of bone objects.

Consequently, based on insufficient coverage of the problem of using X-ray methods in forensic veterinary practice and the lack of wellgrounded osteological algorithms for determining the age of bovine animals, it was necessary to adapt the tested methods used in the study of tubular bones to determine the age of the animal. The purpose of the study is to develop a mathematical model of the proximal phalanx, medial phalanx, and ungular bones of the pelvic limbs of cattle; analyze the dynamics of the X-ray densitometric indices of these bones and propose a way of determining the age of bovine animals according to these indicators.

\section{Material and methods}

The study material consisted of proximal phalanx (os compedale), medial phalanx (os coronale) and ungular (os ungulare) bones of the pelvic limb from cattle aged from newborn up to 12 years of age, namely $0-2,2-4,4-6,6-9,9-14,14-20,20-36,36-60,60-120$ and 120 144 months of age. The study was conducted in 5 bone samples for each bovine age.

X-ray examination of the proximal phalanx, medial phalanx and ungular bone was performed on the Arman apparatus in accordance with the following parameters: the voltage on the tube is $120 \mathrm{kV}$, the focal length of the tube to the X-ray film is $90 \mathrm{~cm}$, the current strength is $210 \mathrm{~mA} / \mathrm{s}$, and the exposure is 3 seconds. X-ray of the metatarsal bones was carried out in the dorso-palmar projection, and the bones of the finger were in the latero-medial with the use of an ND-1 negatoscope.

Using X-Ray 1-V.3 software X-ray test was carried out, the internal and external sections of the tubular bone were determined, scanning the $\mathrm{X}$-ray images on film. The resulting image has the form of a matrix in which each element corresponds to one point in this image. Analyzing the radiograph, its brightness was determined in gradations of shades of grey. At this time, a graph of the distribution of brightness is automatically developed in any selected fragment of the X-ray image of the bone (densitogram). Program analysis of densitograms allows us to automate the process of morphometry of bones with the definition of X-ray densitometric indices (RDP). The results were statistically analyzed in Statistica 8.0 (StatSoft Inc., USA) program pack.

\section{Results}

During the study, a comprehensive optic-geometric description was used, which is a new approach to the quantitative assessment of the state of biological objects, in particular bones. Under these conditions, the optical density (the concentration of matter per unit area or total amount of matter) and the parameters of the object (area, perimeter, boundary, diameter) are analyzed. This allows us to establish the advantages of densitometry and morphometry in expert practice. In the case of deter- mining only the density of bone tissue by the method of indirect X-ray densitometry, the result will be subjective. For X-ray densitometry, scanners are used in combination with software tools that measure the brightness of a computer X-ray image (Fig. 1).

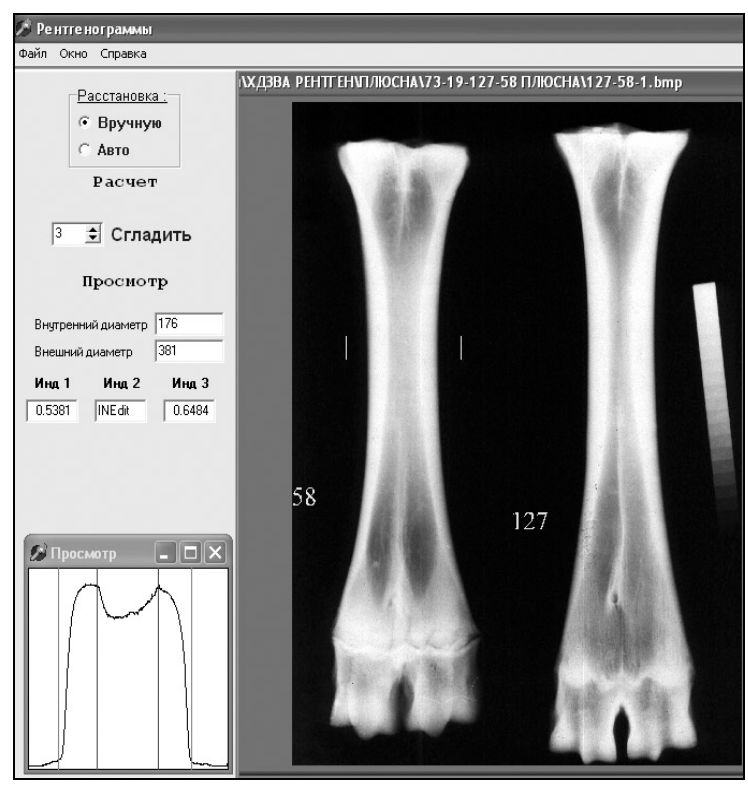

Fig. 1. X-ray of metatarsal bones of cattle, obtained using the software module X-rays V.3

Application of the software module X-rays V.3 allows one to get a full-scale digital X-ray image, carry out a detailed photometric analysis. In mathematical modeling, the process of creating special methods for determining bone tissue parameters is based on a thorough physical and mathematical analysis of the interaction of investigated bones with $\mathrm{X}$-rays. For this purpose, mathematical models of bones are used and their interaction with radiation is described. Therefore, the interaction of bone tissue with X-ray radiation is described mathematically and takes into account the absorption of X-rays by soft tissues surrounding the bone. To do this, we used two measured values determined using X-ray the outer diameter of the thigh (to establish soft tissue compensations of influence of soft tissues and the outer diameter of the femur (to determine the thickness of the bone in the direction of radiation action). We used such a model is used to describe the proximal phalanx, medial phalanx and ungular bones of the pelvic limb of cattle.

To simulate the process of X-ray interaction with bone structure, we apply Bouguer's law (1):

$$
I=I_{0} e^{-\mu y},
$$

where $I$ is the intensity of the radiation that passed through the bone tissue; $I_{0}$ - intensity of radiation in the beginning; $\mu$ - linear coefficient of reduction of radiation; $y$-is the thickness of the irradiated material layer.

The linear weakening factor $\mu$ in formula (l) characterizes the relative change in the intensity of the directed radiation per unit thickness of the substance and has the following relation to the physical parameters of the substance:

$$
\mu=n \sigma=\frac{N_{A} \cdot \rho}{A} \sigma,
$$

where $n$ - number of atoms in the volume of matter; $\sigma$ - coefficient representing the general reliability of the scattering or absorption of a photon by one atom; $N_{A}$ - the Avogadro number; $\rho$ - the density of matter; $A$ is the atomic mass of matter.

Applying knowledge of the laws of the chemical composition of bone tissue, it can be argued that in the case of interaction with it, X-rays are mainly absorbed. Taking into account that the cortical bone matter has a substantially constant density $\left(\rho_{\mathrm{k}}\right)$, then the linear coefficient of attenuation of the radiation by the cortical layer $\left(\mu_{\mathrm{k}}\right)$, is also a constant.

For the calculation of the intensity of the $I_{K}(x)$ of the object's radiation, the formula ( 1 ) determined the thickness distribution $(y(x))$ in the section of compact bone tissue in the direction $Y$. The result of X-ray emission through the investigated object is recorded on its X-ray image (Fig. 2, 3). 


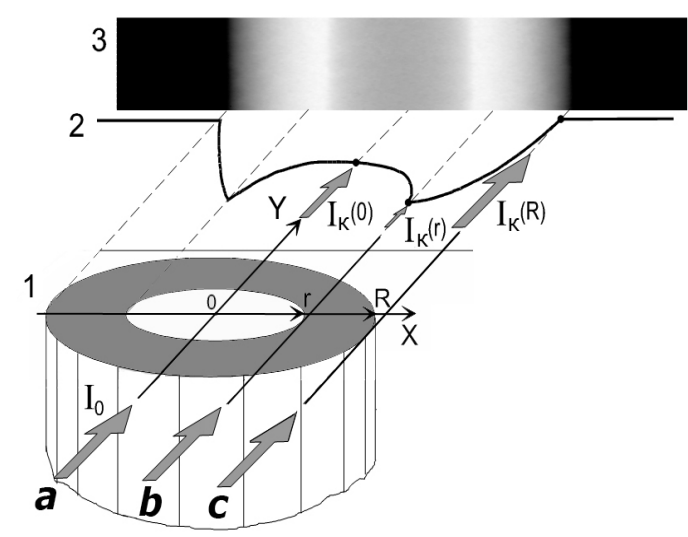

Fig. 2. X-ray image of X-ray emission through a tubular object: 1 - model of the object under study (passing of rays: $a$-along the middle line $(\mathrm{x}=0), b$-along the line of greatest thickness $(\mathrm{x}=\mathrm{r})$,

$c$-by tangent $(\mathrm{x}=\mathrm{R})) ; 2$ - densitogram of the object; 3 -X-ray image of the object
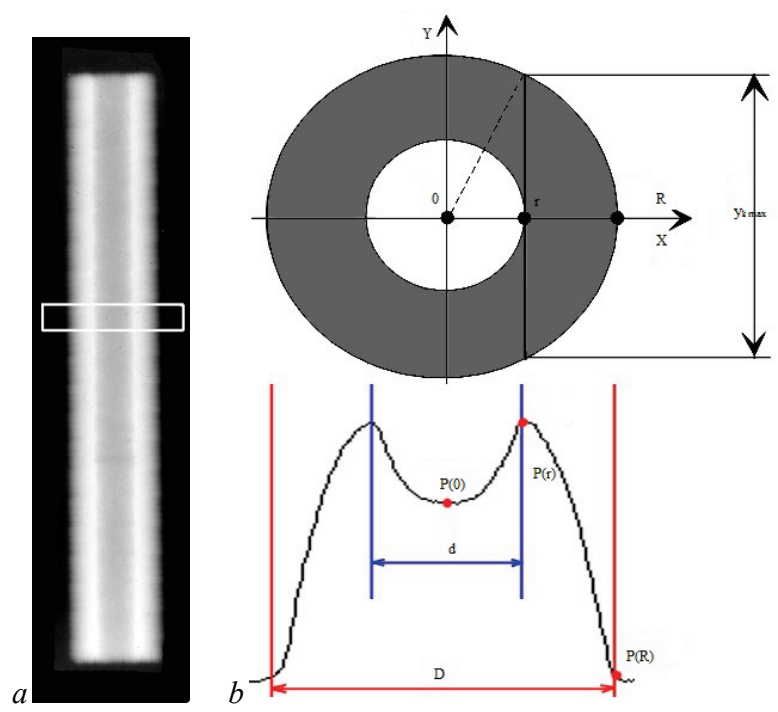

Fig. 3. Roentgenogram, model of normal section $(a)$ and densitogram with characteristic points of tubular object $(b)$

In osteorenentgenology use of X-ray image on negative X-ray films is accepted practice, which allows one to analyze X-ray measurement of bone size. Using the traditional X-ray one can determine the distribution of the optical density of the film $\left(\mathrm{S}_{\Sigma}\right)$, proportional to the distribution of the intensity of the radiation $\left(I_{\Sigma}\right)$ that passed through the object (3):

$$
S_{\Sigma}=\gamma \ln I_{\Sigma}
$$

where $\gamma$ is the film contrast ratio.

The analysis of tubular bones of cattle on a traditional negative X-ray image showed that the optical density is maximum for the background image (where the investigated bone object is absent), and the minimum for the image of the most dense substance of the object. In the case of an analysis of the physical density of the investigated bone object, the more convenient concept is "transparency" $(T)$, which is defined as:

$$
T_{\Sigma}(x)=S_{\max }-S_{\Sigma}(x)
$$

where $S_{\max }$ is the maximum value of the optical density (in this case, $S_{\max }=\gamma\left(\ln I_{0}\right)$.

The maximum value of the function $T_{\Sigma}(x)$ corresponds to the maximum transparency of the negative X-ray film and at the same time reflects the maximum density of the bone tissue depicted in the X-ray.

Investigating the proximal phalanx of cattle, it has been determined that in the middle third it has a tubular heterogeneous structure (Fig. 4a), therefore the mathematical model of the tubular structure is most useful for describing the section of this bone (Fig. 4b). However, only half of the total cross section of this bone can be modeled by half the ring in the thickness $R-r$ (Fig. 4c). For this structure, it is possible to use the calculation of X-ray densitometric indices by the formula (5):

$$
R D P_{\text {com }}=\frac{R_{k}(r)}{2 \sqrt{R^{2}-r^{2}}}
$$

First of all one should determine it exactly $R_{k}(r)$, because of the definition $R_{k}(0)$ for this bone is quite problematic, and especially from that surface, where the cross section of the bone is most similar to the half-circle.
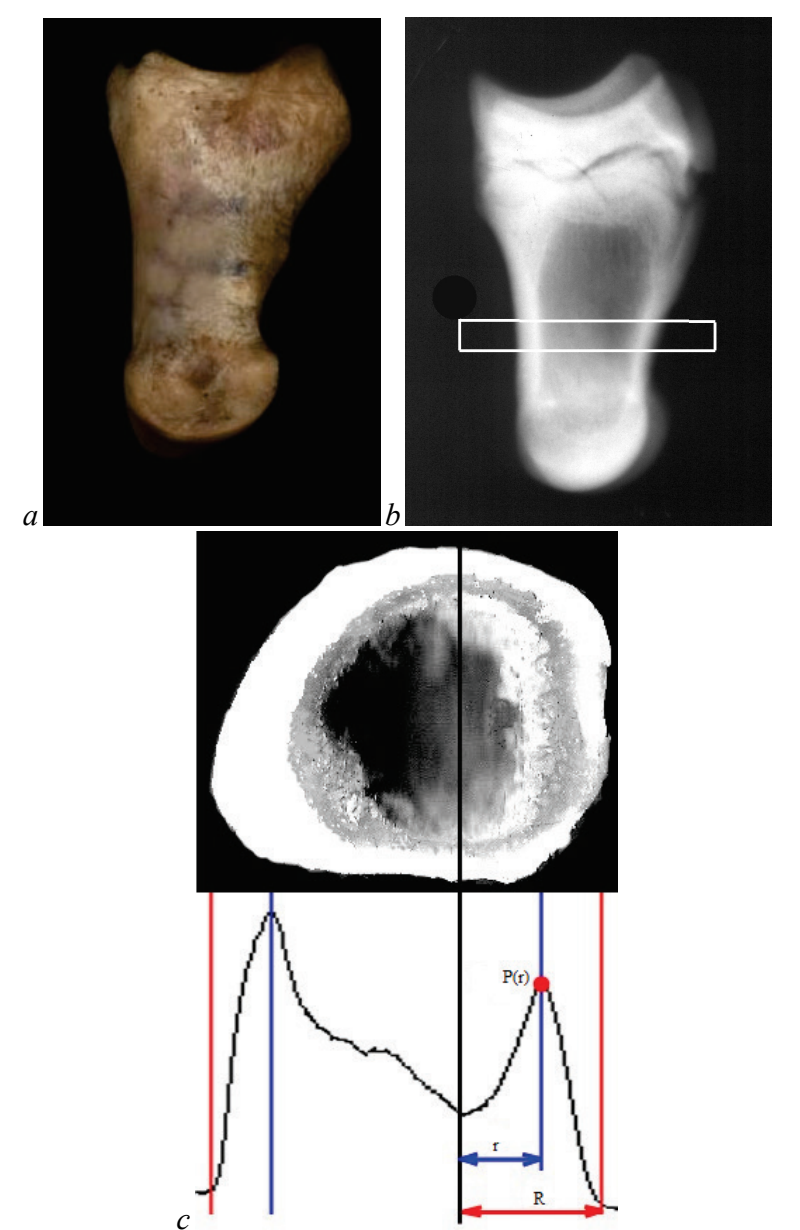

Fig. 4. Proximal phalanx of cattle $(a)$, its radiograph $(b)$ and a macrophoto on a cross section with a densitogram (c)

During the study of the medial phalanx of cattle, it was determined that in the cross-section, it has a cortical layer of triangular shape. On the basis of this, we can create an appropriate model of the cortical layer as a tubular structure of non-circular cross-section. By densitogram of the X-ray image of the medial phalanx of the pelvic limb of the cattle, in the lateral projection, (Fig. $5 b$ ) one can determine the point of maximum brightness $\mathrm{P}_{\max }$ in the selected fragment of the $\mathrm{X}$-ray image. It is easy to determine the length of the bone for this guideline $(L)$ to the point with $\mathrm{P}_{\max }$ and actually the value $\mathrm{P}_{\max }$ (Fig. $5 c$ ).

For the final determination of the X-ray-densitometric parameters of the medial phalanx, in addition to the brightness of the X-ray image at the extreme point of the densitogram, the thickness of the cortical layer in the direction of the active radiation at the same point should be determined. Analyzing the image of the duct of the tubular bone in the section on which the densitogram was developed (Fig. 5c), one can determine the thickness of the cortical layer $2 \mathrm{~h}$ at the point $\mathrm{P}_{\max }$ as doubling the height of the triangle with 200 inclination angle of hypotenuse $(a)$ to the side $(L)$. Then $h=a \sin 20^{\circ}, L=a \cos 20^{\circ}$, but the thickness of the cortical layer at the point $\mathrm{P}_{\max }$ can be defined as $2 h=2 L \cdot \operatorname{tg} 20^{\circ}$. This will allow one to calculate the X-ray densimometric parameters of the medial phalanx as:

$$
\text { RDPcor }=\frac{P_{\max }}{2 L \cdot \operatorname{tg} 20^{0}}=\frac{P_{\max }}{2 L \cdot 0.364} .
$$

$\mathrm{X}$-ray densitometric indices of the cortical layer of the ungular bone are determined for the plantar surface (Fig. 6). The plantar surface of the ungular bone can be entered into a rectangle (Fig. $6 a$ ), the length Lung 
of which can be determined by the densitogram of the X-ray image in the lateral projection (Fig. $6 b, c, d$ ). The width $(h)$ of the ungular bone, according to morphometric studies, for the bovine species animals of different ages, is $0.35 \mathrm{~L}_{\text {ung. }}$. Therefore, in order to determine the X-ray densitometric parameters of the ungular bone, it is necessary to measure the average brightness of the X-ray image of the plantar surface Rung in the middle section. Then the X-ray densitometric parameters of the ungular bone can be defined as follows:

$$
R D \text { Pung }=\frac{R_{\text {ung }}}{h}=\frac{R_{\text {ung }}}{0.35 \times L_{\text {ung }}} .
$$

In the following, we analyzed the relative values of the X-ray densitometric indices of the studied bones. The obtained relative values of $\mathrm{X}$-ray density were calculated taking into account the maximum brightness of the bone tissue and its thickness in a certain area of the bone.

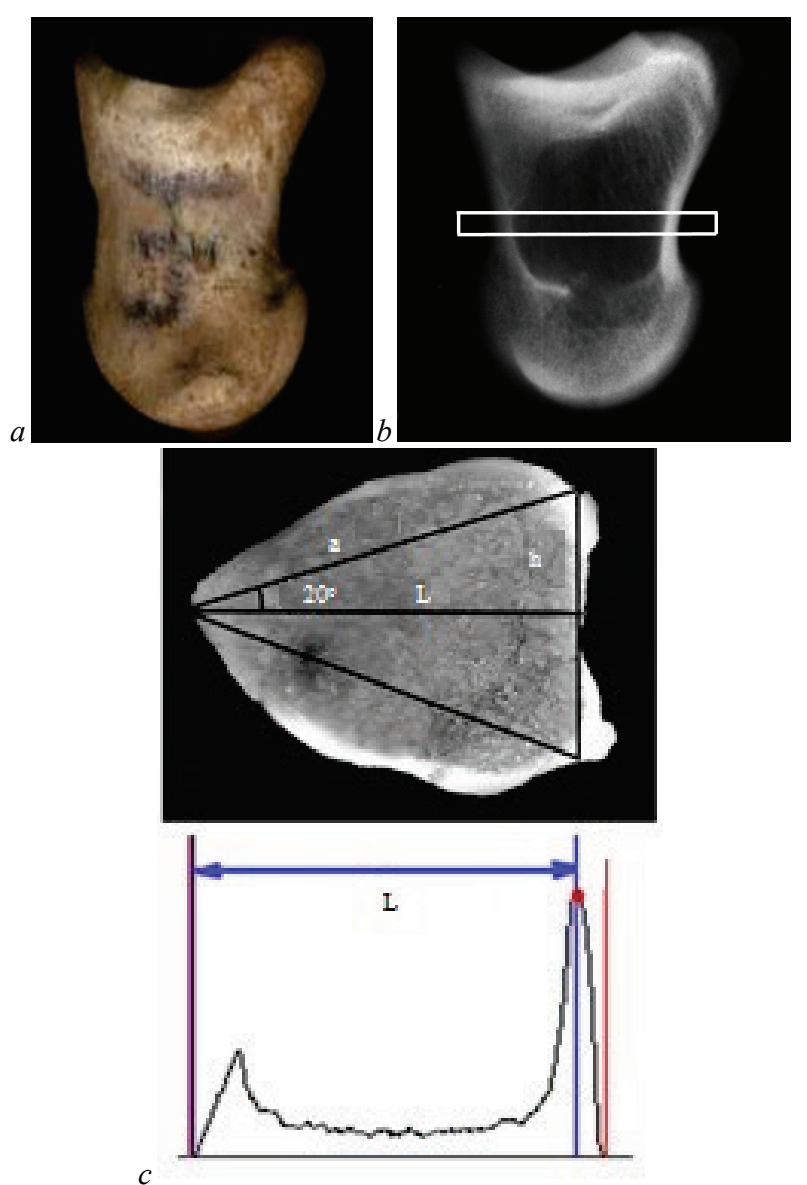

Fig. 5. Medial phalanx (a), radiograph in lateral projection (b); $\mathrm{X}$-ray of the coronary bone on the transverse section with a densitogram $(c)$

It has been established that the general age-specific feature of the dynamics of relative values of the optical density of the proximal phalanx and medial phalanx bones of the pelvic limb is the growth of these indicators from the birth of cattle to 60-month-age ( 5 years), and - ungular bone to 120 -month-age (10 years). In animals older than 60 months of age, the $\mathrm{X}$-ray densitometric indicators of the proximal phalanx and medial phalanx tend to decrease, and X-ray densitometric indices of the ungular bone of the pelvic limb begin to decrease in animals older than 120 months (10 years). The established pattern is the reduction of X-ray densitometric indices of the proximal phalanx, medial phalanx and ungular bones of the pelvic limb in the distal direction (Fig. 7).

Minimum densitometric values of the proximal phalanx, coronary, ungular bones of the pelvic limb was recorded in animals from birth to 2 months of age (Fig. 7), and the maximum intensity of increase in X-ray densitometric indices was recorded in the period from the birth of cattle to 9 months of age. The investigated parameter between these age groups (from birth to 2 months of age and from 2 to 4 months of age) increases in the following sequence: by $30.8 \%$ in ungular bone, by $25.6 \%$ - in the proximal phalanx, by $12.5 \%$ - in the medial phalanx.
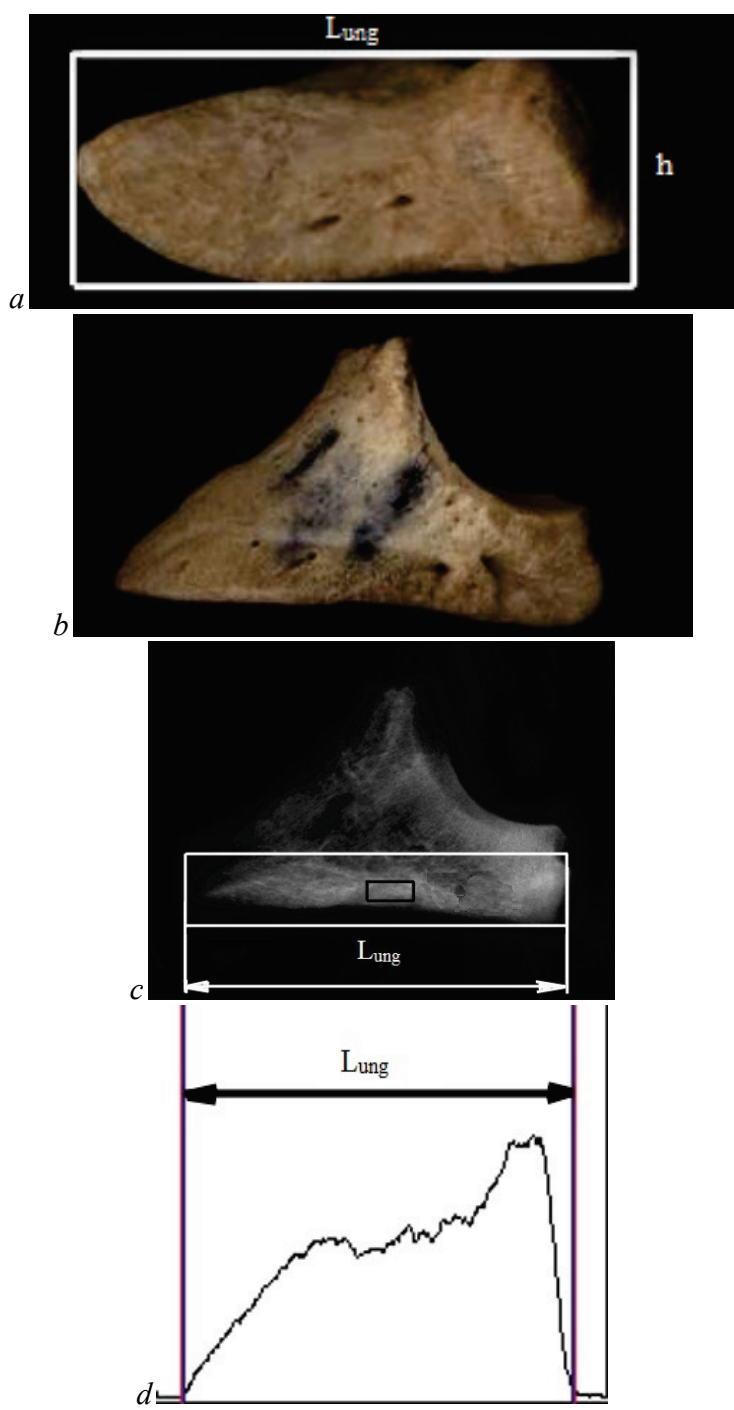

Fig. 6. Ungular bone from the plantar surface $(a)$, lateral surface of the ungular bone $(b)$, radiograph of the lateral projection of the ungular bone with the densitogram $(c, d)$

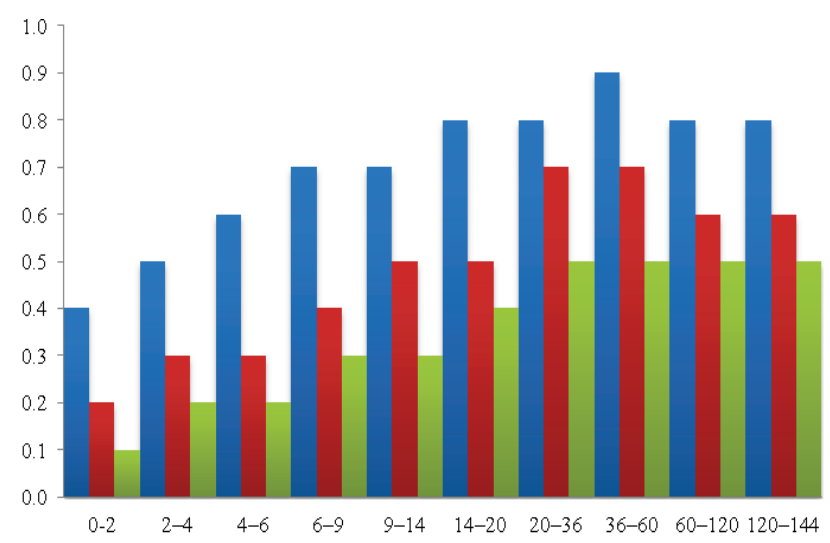

Fig. 7. Age dynamics of $X$-ray densitometric indices of proximal phalanx, medial phalanx and ungular bone of the pelvic limb of cattle: along the abscissa axis - groups of animals (day), along the ordinate axis - optical density; blue column - proximal phalanx; red-medial; green - ungular; $\mathrm{n}=5$

In animals from 2 to 4 months of age and from $4-6$ months of age, the most intensive increases were observed to occur in the X-ray densitometric parameters of the medial phalanx - by $25.9 \%$, the proximal phalanx bone - by $22.4 \%$ and only by $11.8 \%$ - ungular bone. Compared to the previous age groups, there is a reverse trend in the intensity of the increase of the investigated parameter. 
Positive dynamics of increase of X-ray densitometric indices was established from 4 to 6 months and from 6-9 months of age. The maximum increase of this parameter was determined for the ungular bone by $52.6 \%$. At the same time, the indicators of medial phalanx increased by $29.4 \%$, and the minimum value of this parameter in this period was observed for the proximal phalanx bone $-8.3 \%$.

With age, the increase in X-ray densitometric indicators (20-36 and $60-120$ months) continues, but the intensity of this process is significantly reduced. The maximum increase in the investigated parameter was determined for the ungular bone - by $13.8 \%$, the value for the proximal phalanx bone was $9.2 \%$ and the medial phalanx was $6.8 \%$.

Compared to the above-mentioned age periods, an increase in X-ray densitometric indices was established in animals 9-14 and 14-20 months. The maximum increase in X-ray densitometric indices was again characteristic of the ungular bone - by $24.2 \%$, somewhat less intensity was observed in the medial phalanx - by $10.6 \%$, even lower in the proximal phalanx bone - by $9.9 \%$.

Densitometric indices continue to increase in animals 14-20 and 20-36 months of age. The maximum intensity of increase of the investigated parameter was determined in the medial phalanx - by $25.0 \%$, somewhat less intensity was characteristic for the ungular bone $19.5 \%$, in the proximal phalanx - by $7.7 \%$. A peculiarity is that at the age 20-36 month old, the densitometric parameters of the bone marrow reach maximum values.

The tendency towards increase in X-ray densitometric parameters remains in animals 20-36 and 36-60 months, however, in the majority of cases, the intensity of this process is significantly reduced. The maximum intensity of the increase in the investigated parameter was determined in the ungular bone - by $8.2 \%$, in the medial phalanx - by $1.5 \%$, and in the proximal phalanx the value of X-ray densitometric indicators remains constant. In this age period, the values of X-ray densitometric indicators of the medial phalanx reach maximum.

In the period 60-144 months of age there is a tendency to decrease in the values of X-ray densitometric indices, with the exception of the ungular bone. In the period 36-60 and 60-120 months of age, the decrease of X-ray densitiometric indices was determined: $3.1 \%$ in the medial phalanx and $1.2 \%$ in the proximal phalanx. During this age there is a tendency to increase - by $1.9 \%$ of X-ray densitometric indicators of the ungular bone. In animals 60-120 and 120-144 months of age, the values of X-ray densitometric indices for all studied bones tend to decrease. Particularly, X-ray densitometric parameters of the proximal phalanx were reduced by $6.4 \%$, by $5.9 \%$ in the ungular bone and by $1.6 \%$ in the medial phalanx. Consequently, the age dynamics of the metatarsal bones and the fingers of the pelvic limb of cattle is characterized by periods of constant increase in X-ray densitometric indices, while the data for the proximal phalanx reaches the maximum values at age 20-36 months, for the medial phalanx at the age of 36-60 months, and for the ungular bone at the age of 60-120 months. In the following age groups there is a tendency to decrease in these indicators.

Taking into account the age-specific features of the dynamics of $\mathrm{X}$-ray densitometric indicators, a regression analysis of the proximal phalanx, medial phalanx and ungular bones of the pelvic limb was performed. It was established that the relationship between the age of cattle and the studied densitometric indices for proximal phalanx, medial phalanx and ungular bones is described using nonlinear and linear regression equations that are individual for each of the tubular bones (Table 1). The equation of linear and nonlinear regression was able to be combined into one for the use of the Heaviside step theta function. By the values of the determination coefficients, it was established that there is a close correlation between the age of cattle and X-ray densitometric indices of the proximal phalanx, medial phalanx and ungular bones of the pelvic limb. In order to determine the informativity of the calculated regression equations for diagnosing the age of cattle, their testing in the "blind method of investigation" was performed. To do this, a separate collection of the studied pelvic limb bones was created with their consistent X-ray and scan. From digital X-ray images, X-ray densitometric parameters were obtained using X-Reus software. The obtained values were used to calculate the age of bovine animals, using the corresponding regression equations. Age was determined in months.
Table 1

Results of regression analysis of proximal phalanx, coronary and ungular bone of the pelvic limb of cattle

\begin{tabular}{|c|c|c|c|c|}
\hline Bones & Regression equation & $\begin{array}{l}\text { Coeffi- } \\
\text { cient de- } \\
\text { termina- } \\
\text { tion, }\left(R^{2}\right)\end{array}$ & $\begin{array}{c}\text { Diagnostic } \\
\text { limits of } \\
\text { equation, } \\
\text { month }\end{array}$ & $\begin{array}{c}\text { Average } \\
\text { estima- } \\
\text { ted error, } \\
\mathrm{m}\end{array}$ \\
\hline $\begin{array}{l}\text { Proximal } \\
\text { phalanx }\end{array}$ & $\begin{array}{l}\mathrm{r}_{1}=5954.01 x^{4}-13443.20 x^{3}+11243.2 x^{2} \\
-4094.3 x+547.51\end{array}$ & 95.0 & $0-60$ & 3.3 \\
\hline Medial & $\begin{array}{l}\mathrm{r}_{1}=850.65 x^{3}-901.0 x^{2}+349.26 x- \\
42.67\end{array}$ & 95.0 & $0-60$ & 3.3 \\
\hline Ungular & $\begin{array}{l}\mathrm{r}_{1}=\left(1921.65 x^{3}-1571.03 x^{2}+446.79 x\right. \\
-35.84) \\
{ }^{*} \text { Heviside }(0.5-x)+\left(29199.11 \mathrm{x}^{4}-\right. \\
34129.55 x^{3}+14056.08 x^{2}-2348.91 x+ \\
137.40)\end{array}$ & 99.0 & $0-120$ & 4.0 \\
\hline
\end{tabular}

Note: * - Heaviside step theta function.

\section{Discussion}

According to the results of the experimental study, it was found that the informativeness of each of the studied bones was close to the X-ray densitometric indices. The criterion of informativeness in each case was the value of the average calculation error (the average of the arithmetic sum of the difference between the actual and estimated age). According to X-ray densitometric parameters of the proximal phalanx and medial phalanx, the age of cattle can be diagnosed from birth to 60 months, and according to the parameters of the ungular bone - from birth to 120 months.

The specialised scientific literature describes the results of radiographic studies of bones, both axial and peripheral sections of the skeleton, including in forensic veterinary expertise. Currently, scientists have determined that the $\mathrm{x}$-ray criteria of the bones of the distal parts of the free thoracic limbs of bovine cattle are informative. Thus, diagnosis of cattle age according to osteoscopic and radiographic signs of metacarpal bones and ungular bone is possible by three age ranges $-0-2,2-36$ and 36-144 months. The determined macroscopic markers of cattle age have been established: according to the bones of metacarpal - the of the pronounced roughness of the third bone of the metacarpus, the presence or absence of metaphyseal cartilage, epiphyseal-diaphyseal synostosis, and the form of the distal canal of the metacarpus; according to the ungular - the severity of exostoses, the relief of the plantar surface and osteoporosis (Bondarevskyi et al., 2012; Yatsenko et al., 2013).

Scientists have proven that the morphological parameters of the biological material are extremely informative in the course of diagnostic research, in particular, to determine in the course of forensic examination the species, sex, time of death and burial (Abuznaid, 2016; Abuznaid, 2016) in both animal and human medicine (Shanbhogue et al., 2015; Chung et al., 2018). The skeleton is the most informative object for these tasks, because changes in the bones persist for a long time, and soft tissues decay quickly. Bone tissue is the most durable, but is also labile, because it "responds" to the dynamics of metabolic processes in the body (Suster, 2013). According to the macro- and microscopic features of the structure of tubular bones, one can determine both the species and age, the presence of possible pathologies in the organism of animal, determine the time of its death and natural disintegration or deliberate destruction of the remains. By some bones it is possible to establish the sex of an animal, the conditions of its maintenance, the physiological state of the organism, etc. Of particular importance is the ability to detect probable bone parameters during the veterinary and sanitary examination (Tkachuk \& Stoliarchuk, 2011). This is because bone tissue is a sufficiently dynamic structure capable of continuous renewal by combining osteogenesis and resorption processes. One of the indicators of the growth and development of skeletal bones is the change in the ratio between the quantitative and qualitative indices of organic and inorganic bone matter. These age characteristics can be detected using a number of modern methods: electron microscopy, $\mathrm{X}$-ray analysis, X-ray densitometry. According to X-ray densitometric methods, it is possible to accurately and objectively identify the degree 
of mineral saturation of the bone tissue. In the case of poaching or theft of animals, distal parts of the animal limbs, which have low commodity value, may be abandoned not far from the place where the crime was committed. Therefore, conducting the examination procedure for distal limbs is extremely important. However, these procedures, based not only on macrostructural indices of tubular bones of animals, but also on knowledge of their variability in spectroscopic, radiological and other parameters in the wide age range, are absent. This goal can be achieved by creating a special methodological literature, systematic research, development of appropriate computer technologies (Kamianskyi, 2010).

Our research has established that Bouger's law describes the process of interaction of X-rays with bone tissue of the proximal phalanx, medial phalanx and ungular bones of the pelvic fins of cattle. Based on this law, we have developed mathematical models of this interaction and presented an algorithm for analyzing the data obtained to determine the age of cattle, taking into account the X-ray densitometric indices of the studied pelvic limb bones.

\section{Conclusions}

The process of interaction of X-rays with the bone structure of the proximal phalanx, medial phalanx and ungular bones of the pelvic limbs of cattle occurs according to Bouguer's law. The mathematical modeling of this interaction and the corresponding algorithm for the analysis of the data obtained is the basic way of determining the age of bovine cattle by X-ray densitometric indices of the proximal phalanx, medial phalanx and ungular bones of the pelvic limbs. According to the $\mathrm{X}$-ray densitometric indices of the proximal phalanx and medial phalanx bones of the pelvic limbs, the age of the animal from birth to 5 years was diagnosed, and on ungular bones - from birth to 10 years. It has been experimentally proved that X-ray of medial phalanx and ungular bone of pelvic limb is a necessary method for diagnosing age of cattle in combination with other morphological, chemical and physical methods of investigation.

\section{References}

Abuznaid, K. R. S. (2016). Zastosuvannia KT-densytometriji v doslidzhenni morfolohichnykh parametriv velykoji rohatoji khudoby [Application of KT-densitometry in the study of morphological parameters of cattle]. Radioelektronika ta modeli XXI stolittia: Materialy XX yuvileinoho mizhnarodnoho molodizhnoho forumu. Vol. 1, 88-90 (in Ukrainian).

Abuznaid, K. R. S. (2016). Znachennia morfolohichnykh parametriv kistok skeleta dlia vyrishennia diahnostychnykh zavdan suduvo-veterynarnoji ekspertyzy [The value of the morphological parameters of skeleton bone for solving diagnostic problems in the forensic-veterinary inspection]. Problemy Zootekhniji ta Veterynarnoji Medytsyny, 29, 228-249 (in Ukrainian).

Amadasi, A., Borgonovo, S., Brandone, A., Mauro, A., Di Giancamillo, M., \& Cattaneo, C. (2014). A comparison between digital radiography, computed tomography and magnetic resonance in the detection of gunshot residues in burnt tissues and bone. Journal of Forensic Sciences, 59(3), 712-717.

Bondarevskyi, M. M., Yatsenko, I. V., \& Averianova, L. O. (2012). Renthenodensytometrychni pokaznyky kistok plesna, yak kryteriji diahnostyky viku velykoji rohatoji khudoby u sudovij veterynarnij medytsyni [X-ray densitometric indices of metatarsal bones as a criterion for diagnosing cattle's age in forensic-veterinary inspection]. Visnyk Zhytomyrskoho Derzhavnoho Ahroekolohichnoho Universytetu, 32, 227-231 (in Ukrainian).

Chung, C., Chen, Y.-P., Leu, T.-H., \& Sun, C.-W. (2018). Near-infrared bone densitometry: A feasibility study on distal radius measurement. Journal of Biophotonics, 11(7), e201700342.

Coates, D. B., Dixon, R. M., Murray, R. M., Mayer, R. J., \& Miller, C. P. (2016). Bone mineral density in the tail-bones of cattle: Effect of dietary phosphorus status, liveweight, age and physiological status. Animal Production Science, 58(5), 801-810.

Davies, H. M. S. (2010). Dorsal metacarpal cortex ultrasound speed and bone size and shape. Equine Veterinary Journal, 34, 337-339.
Dicken, A. J., Evans, J. P. O., Rogers, K. D., Stone, N., Greenwood, C., Godber, S. X., Prokopiou, D., Clement, J. G., Lyburn, I. D., Martin, R. M., \& Zioupos, P. (2015). X-ray diffraction from bone employing annular and semiannular beams. Physiology Medicine Biology, 60, 5803-5812.

Girdis, C. M., Baldock, P. A., \& Downes, M. (2015). Vitamin D, muscle and bone: Integraring effects in development, aging and injury. Molecular and Endocrinolody, 410, 3-10.

Jimenez-Mendoza, D., Espinosa-Arbelaez, D. G., Giraldo-Betancur, A. L., Hernandez-Urbiola, M. I., Vargas-Vazquez, D., \& Rodriguez-Garcia, M. E. (2011). Single X-ray transmission system for bone mineral density determination. Review of Scientific Instruments, 82(12), 105-125.

Kamianskyi, V. V. (2010). Makroosteoskopichnyi analiz deiakykh kistok paltsiv dlia vyznachennia viku velykoi rohatoi khudoby u sudovo-veterynarnij ekspertyzi [Macroosteoscopic analysis of some bones of the finger for determining the age of cattle in the forensic-veterinary inspection]. Visnyk Poltavskoi Derzhavnoi Ahrarnoji Akademiji, 1, 214-218 (in Ukrainian).

Keene, B. E., Knowlton, K. F., McGilliard, M. L., Lawrence, L. A., NickolsRichardson, S. M., Wilson, J. H., Rutledge, A. M., McDowell, L. R., \& Van Amburgh, M. E. (2004). Measures of bone mineral content in mature dairy cows. Journal of Dairy Science, 87(1), 3816-3825.

McClure, S. R., Glickman, L. T., Glickman, N. W., \& Weaver, C. M. (2001). Evaluation of dual energy X-ray absorptiometry for in situ measurement of bone mineral density of equine metacarpi. American Journal of Veterinary Research, 62(5), 752-756.

Monfared, A. L. (2013). Gross anatomical measurements of the head region of the iranian native cattle (Bos taurus) and their clinical value for regional anesthesia. Global Veterinaria, 10(2), 219-222.

Mostafa, E. M., El-Elemi, A. H., El-Beblawy, M. A., \& Dawood, A. E.-W. A. (2012). Adult sex identification using digital radiographs of the proximal epiphysis of the femur. Suez Canal University Hospital in Ismailia, Egyptian Journal Forensic Science, 2(3), 81-88.

Shanbhogue, V. V., Hansen, S., Folkestad, L., Brixen, K., \&Beck-Nielsen, S. S. (2015). Bone geometry, volumetric density, microarchitecture and estimated bone strength assessed by HR-pQCT in adult patients with hypophosphatemic rickets. Journal of Bone and Mineral Research, 30(1), 176-183.

Sidoroff, V. H., Ylinen, M. K., Kröger, L. M., Kröger, H. P. J., \&Korppi, M. O. (2013). Inhaled corticosteroids and bone mineral density at school age: A follow-up study after early childhood wheezing. Pediatric Pulmonology, 50(1), 1-7.

Stynder, D. D. (2008). The impact of medium-sized canids on a seal bone assemblage from Dunefield Midden, West Coast, South Africa. The South African Archaeological Bulletin, 63, 159-163.

Suster, D., Leury, B. J., Ostrowska, E., Butler, K. L., Kerton, D. J., Wark, J. D., \& Dunshea, F. R. (2013). Accuracy of dual energy X-ray absorptiometry (DXA), weight and P2 back fat to predict whole body and carcass composition in pigs within and across experiment. Journal of Dairy Science, 84(3), 231-242.

Tkachuk, S. A., \& Stoliarchuk, L. V. (2011). Vyznachennia vydovoji nalezhnosti miasa velykoji rohatoji khudoby vymiriuvanniam mikrotverdosti trubchastykh kistok [Determination of the species belonging to cattle meat by measuring the microhardness of tubular bones]. Naukovi Dopovidi of National University of Life and Environmental Sciences of Ukraine, 29, 1-7.

Turner, C. H. (2006.) Bone strength: Current concepts. Skeletal Development and Remodeling in Health, Disease and Aging, 1068, 429-446.

Yatsenko, I. V., Bondarevskyi, M. M., \& Kamianskyi, V. V. (2013). Vikova renthenostrukturna kharakterystyka kistok plesna velykoji rohatoji khudoby $\mathrm{v}$ aspekti sudovoji veterynarnoji ekspertyzy [X-ray structural characteristic of cattle bones in the aspect of forensic-veterinary inspection]. Problemy Zooinzhenerii ta Veterynarnoi Medytsyny, 26(2), 274-280 (in Ukrainian).

Zotti, A., Gianesela, M., Ceccato, C., \& Morgante, M. (2009). Physiological values and factors affecting the metacarpal bone density of healthy feedlot beef cattle as measured by dualenergy X-ray absorptiometry. Journal of Animal Physiology and Animal Nutrition, 94(5), 615-622.

Zotti, A., Gianesela, M., Ceccato, C., \& Morgante, M. (2009). Physiological values and factors affecting the metacarpal bone density of healthy feedlot beef cattle as measured by dualenergy X-ray absorptiometry. Journal of Animal Physiology and Animal Nutrition, 94(5), 615-622.

Zotti, A., Poggi, R., \& Cozzi, B. (2010). Exceptional bone density DXA values of the rostrum of a deep-diving marine mammal: A new technical insight in the adaptation of bone to aquatic life. Skeletal Radiology, 38, 1123-1125.

Zotti, A., Poggi, R., \& Cozzi, B. (2010). Exceptional bone density DXA values of the rostrum of a deep-diving marine mammal: A new technical insight in the adaptation of bone to aquatic life. Skeletal Radiology, 38, 1123-1125. 